\title{
The optical analysis of the abdominal wall using the biospeckle after implants of polypropylene mesh in rats ${ }^{1}$
}

\author{
Análise ótica da parede abdominal pelo biospeckle após implante de prótese de polipropileno \\ em ratos
}

\author{
Tâmara Maria Nieri', Marco Antonio de Oliveira Peres ${ }^{\mathrm{II}}$, Emerson Rodrigo da Silva ${ }^{\mathrm{III}}$, Inácio Maria Dal Fabbro ${ }^{\mathrm{IV}}$, Mikiya \\ Muramatsuv, Nelson Adami Andreollovi \\ I $\mathrm{PhD}$ in Surgery, UNICAMP, Campinas-SP, Brazil.

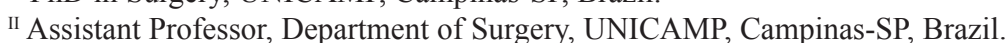 \\ III Fellow Master Degree, Post-Graduate Program, Institute of Physics, USP, Sao Paulo, Brazil. \\ ${ }^{\text {IV }}$ Full Professor, Agricultural Engineering, UNICAMP, Campinas-SP, Brazil. \\ ${ }^{v}$ Associate Professor of Physics, Institute of Physics, USP, Sao Paulo, Brazil. \\ ${ }^{\text {VI }}$ Full Professor of Surgery, Department of Surgery, UNICAMP, Campinas-SP, Brazil.
}

\begin{abstract}
Purpose: To evaluate an experimental animal model to study the abdominal tissue activity considering its interaction with a polypropylene mesh, through the use of one of the optical phenomena of light Laser, the biospeckle. Methods: Fifty Wistar male rats were divided into four groups: Group 1: ten animals not submitted to surgery; Group 2: ten animals submitted to surgery without polypropylene mesh; Group 3: 20 animals submitted to surgery followed by the mesh placement; Group 4: (sham) with ten animals. None of the animals presented post surgical complications being submitted to the optical tests at the 20th postoperative day. Results: The analysis from the biospeckle tests, comparing the medians and standard deviations with T Student test, indicated that no significative difference was observed on the abdominal wall tissue activity in the four groups considered, with and without polypropylene mesh prosthesis implantation. Conclusion: The animal model is viable and the biospeckle open ways for a great number of experiments to be developed in evaluating tissue activity.
\end{abstract}

Key words: Hernia, Abdominal. Polypropylenes. Lasers. Rats.

\section{RESUMO}

Objetivo: Avaliar o modelo experimental animal para o estudo da atividade tecidual da parede abdominal em sua interação com a prótese de polipropileno, através da utilização de um dos fenômenos ópticos da luz Laser, o biospeckle. Métodos: Foram utilizados 50 ratos Wistar machos, divididos em quatro grupos: Grupo 1 com 10 animais não operados e controles; Grupo 2 com 10 animais submetidos a cirurgia sem a colocação de prótese; Grupo 3 com 20 animais submetidos a cirurgia com colocação de prótese de polipropileno pré-peritonial; Grupo 4 (Sham) com 10 animais. Nenhum animal apresentou complicações pós-operatórias, sendo que no $20^{\circ}$ PO foram submetidos ao ensaio óptico. Resultados: A comparação das médias e o desvio padrão das medidas da atividade tecidual da parede abdominal, com e sem implantação da prótese de polipropileno obtidas dos grupos de animais, pelo teste T de Student, não evidenciou diferença estatística significativa ( $\mathrm{p}>0.05)$. Conclusão: A análise dos dados obtidos permitiu concluir que o modelo animal é viável e que o biospeckle abre caminhos para toda uma linha de experimentos a ser desenvolvida em avaliar atividade tecidual.

Descritores: Hérnia Abdominal. Polipropilenos. Lasers. Ratos.

${ }^{1}$ Research performed at the Department of Surgery, School of Medical Sciences and Faculty of Agricultural Engineering, State University of Campinas (UNICAMP) and Laboratory of Optical and General Physics Department, Institute of Physic, University of Sao Paulo (USP), Brazil.

\section{Introduction}

The polypropylene meshs have been used from the end of the fifties, so much in abdominal hernias, as in reconstructions of defects of the abdominal wall after wide tumour exeresis ${ }^{1,2,3}$. The largest use of the meshs in herniorrhaphies, mainly in the abdominal wall, it has been reaching smaller recurrence taxes of these diseases ${ }^{4,5,6,7,8}$
Abdominal wall hernia is a late complication that happens in 2 to $15 \%$ of all laparotomies ${ }^{9,10,11,12}$. Several studies have been associated with different methods of evaluation of the bio-compatibility of the prosthetic materials, in experimental ${ }^{13,14,15,16,17,18,19}$ works and clinical ${ }^{2,3,6,10,12,20,21,22}$ experimental Models allow detailed studies of these interactions, in the field of the anatomy, of the physiology, of the biochemistry, of the microbiology and of the mechanics, but little on tissue activity ${ }^{13}$. 
The present study consisted of the creation of an animal model, that it was shown viable, for the study of the tissue activity of the abdominal wall during the wound healing, so much without prosthesis, as their interactions with prosthesis, through the use of one of the optical phenomena of the Laser (Ligth Amplification by Stimulated Emission of Radiation), the biospeckle.

The biospeckle is an interference illustration formed by the diffuse reflection of the dispersed coherent light when interacting with an object that presents some activity type, biological or not. The interference pattern modifies along the time due to the responsible structures for the dispersal be in activity. That phenomenon has been studied with the intention of developing a fast method and no destructive for evaluation of biological materials ${ }^{23,24}$. It can be evaluated, besides, viability of seeds with the dynamic biospeckle ${ }^{25}$.

The combination, now available, of acquisition systems and digital processing of images are an important tool for the researchers to develop new evaluation techniques no destructive. Systems that use a source of the Laser and a group of acquisition devices and processing of images, they have been referred in the literature as artificial vision, machine vision or as Laser vision. A system of vision artificial Laser is composed by a source of light Laser, a camera for reception of images, a monitor, a digital processor of images and a microcomputer ${ }^{25}$.

The objective was the development of an animal model for the study of the tissue activity of the abdominal wall and its interaction with polypropylene mesh, through the use of one of the optical phenomena of the light Laser, the biospeckle.

\section{Methods}

Fifty randomly male Wistar rats, age of approximately 60 days, weighing between $350 \mathrm{gr}$ and $400 \mathrm{gr}$ were studied. The animals were placed in cages lined with sawdust and kept at the Experimental Surgical Center of the Department of Surgery at UNICAMP, Brazil. The Ethics Committee in Animal Experimentation of the Institute of Biology of UNICAMP gave its favorable opinion to the experiment. The optical researchs were performed at the Laboratory of Optical and General Physics Department, Physics' Institute at the University of São Paulo (USP).

Forty animals were submitted to the surgical procedure and other ten animals, no operated, they formed the control group:

Group 1: Control Group: 10 animals, that they were not submitted to the surgery, just to the biospeckle.

Group 2: Control Group without meshs: 10 animals submitted to the medium laparotomy of the abdominal wall, following by closing for simple suture. The animals were submitted to the biospeckle in the 20th postoperative day.

Group 3: Group with meshs: 20 animals submitted to the medium laparotomy of the abdominal wall, dissecting the parietal peritoneum, fixation of the polypropylene mesh in pre-peritoneal position and closing the abdomen in anatomic plans. The animals were submitted to the biospeckle in the 20th postoperative day.

Group 4: Sham: 10 animals, with the laparotomy of the abdominal wall, dissecting of the parietal peritoneum and closing the abdomen for anatomic plans. The animals were submitted to the biospeckle in the 20th postoperative day.

\section{Surgical procedures}

No preoperative preparation was made, just fast of 2 hours. Intravenous general anesthesia were applied using sodium pentobarbital $(30 \mathrm{mg} / \mathrm{Kg} / \mathrm{rat})$ injected in the tail vein. After laparotomy and opening the aponeurosis, the peritoneum was dissected and the popypropylene mesh sutured using 5-0 polypropylene, between the peritoneum and aponeurosis. After that, the aponeurosis was closed again using continuous thread of 4-0 polypropylene. The skin received separate stitches with 4-0 polygalactin. The animals had free access soon to the water and food after the surgery, being inspected daily.

\section{Optical studies}

The optical studies were performed at the 20th postoperative day in an Optical Table, with a source of light Laser of He-Ne (wavelength. $=632,8 \mathrm{~nm}$ ) and a system of image acquisition (LSI), composed by a camera (Charge Coupled Device. CCD), a monitor, an image digital processor and a microcomputer (Figures 1 and 2).

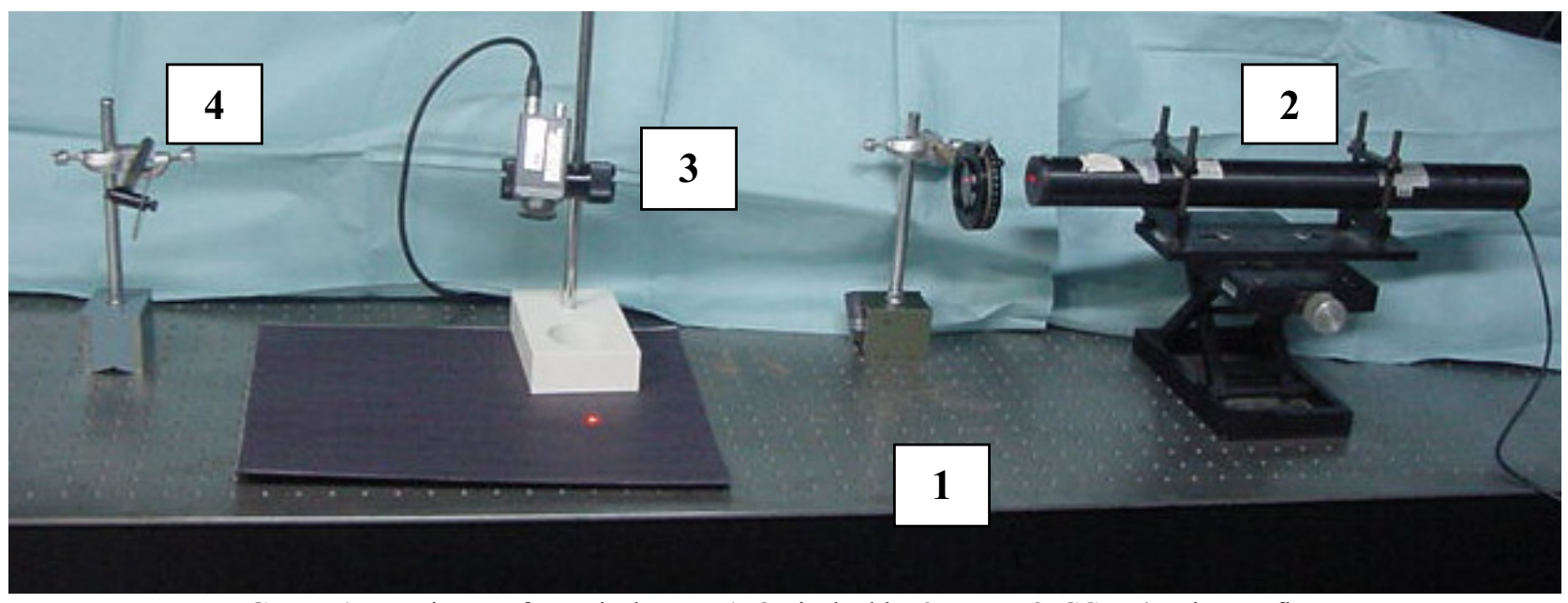

FIGURE 1 - Equipment for optical essay. 1. Optical table; 2. Laser; 3. CCD; 4. Mirror reflector 


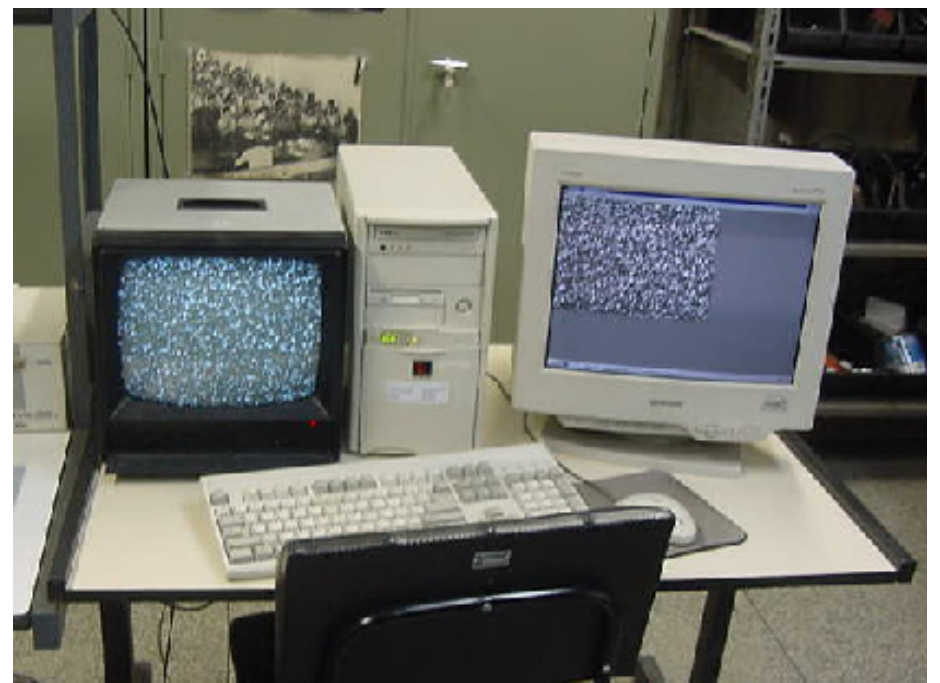

FIGURE 2 - Microcomputador with image digital software

For the optical studies the animal was anesthetized, following the same procedure used in the surgery. Following, they were put in the surgical base, in horizontal decubitus, being positioned so that the luminous point of the Laser happened in the medium line of the abdominal wall, during all the time of image acquisition of the biospeckle, that its were processed by a specific software (Figure 3).

Each image captured during the optical studies generated a pattern STS (Space-Time Speckle), that illustrates the temporary and space variations of the speckle (Figure 4). This STS was processed by a software, generating a Matrix of Occurrences Modified (MOM), that supplies a visual information of the activity of the tissue studied $^{25}$ (Figure 5). Finally, it was calculated the Module of Dispersion, an absolute numeric value, that was the parameter used in the comparison of the specimens.

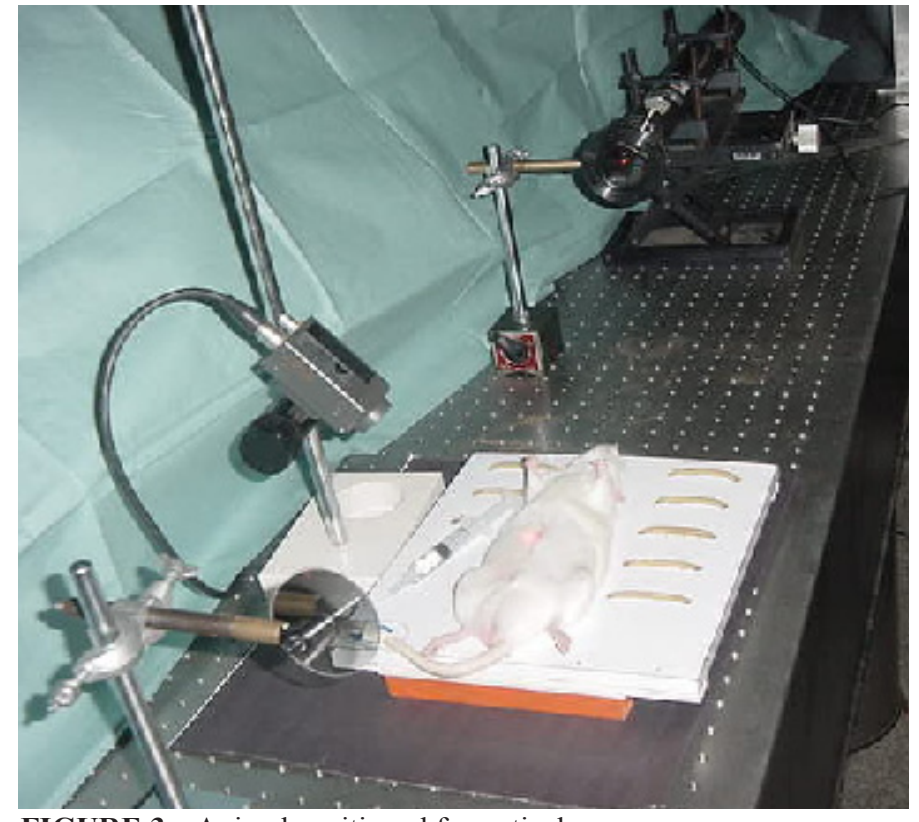

FIGURE 3 - Animal positioned for optical essay

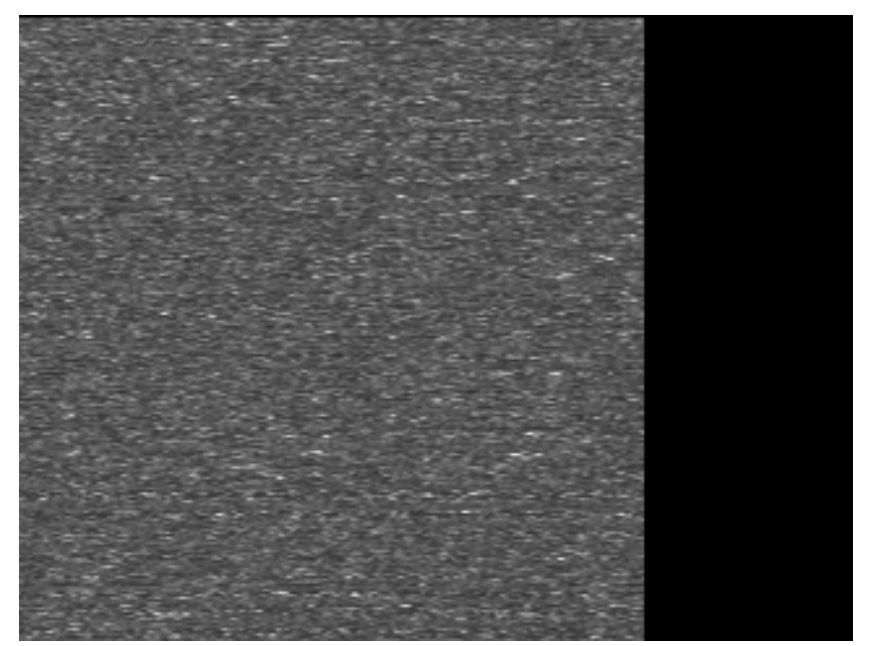

FIGURE 4 - Example of the STS pattern

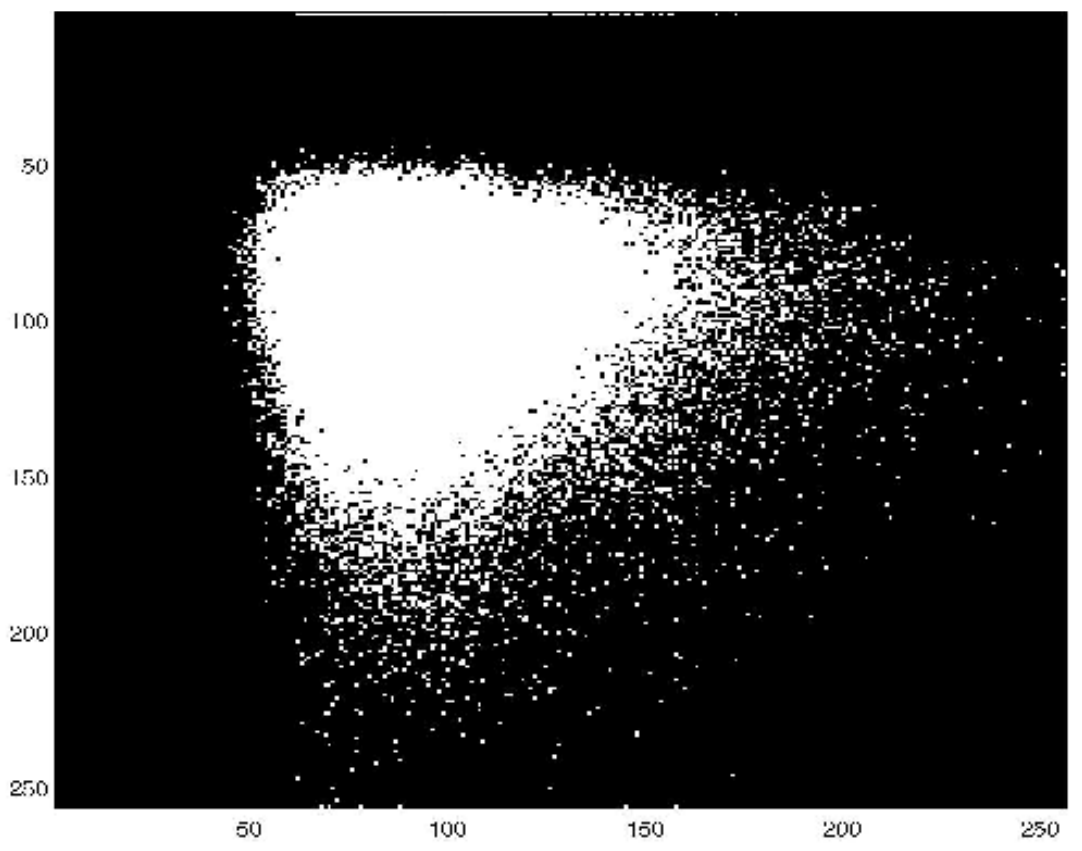

FIGURE 5 - The MOM that corresponds of the STS example of Figure 4 


\section{Results}

None of the animals included in the study presented postoperative complications, and all of them evidenced surgical scars of good aspect in the optical studies. The opening of the abdominal wall after the optical test, performed to the evaluation of the implant, it showed good aspect of the cavity, few adherences and the complete incorporation of the popypropylene mesh to the muscular plan.

The Figures 6 and 7 show the processed images of the optical studies (STS) and the matrix corresponding to each one of them (MOM), in the study of the polypropylene mesh. As a consequence of the program used in this study, the time was plotted in the axis of the ordinates (vertical, in descending sense), what made STS of the polypropylene mesh (STS of low activity) like to a vertical blind.

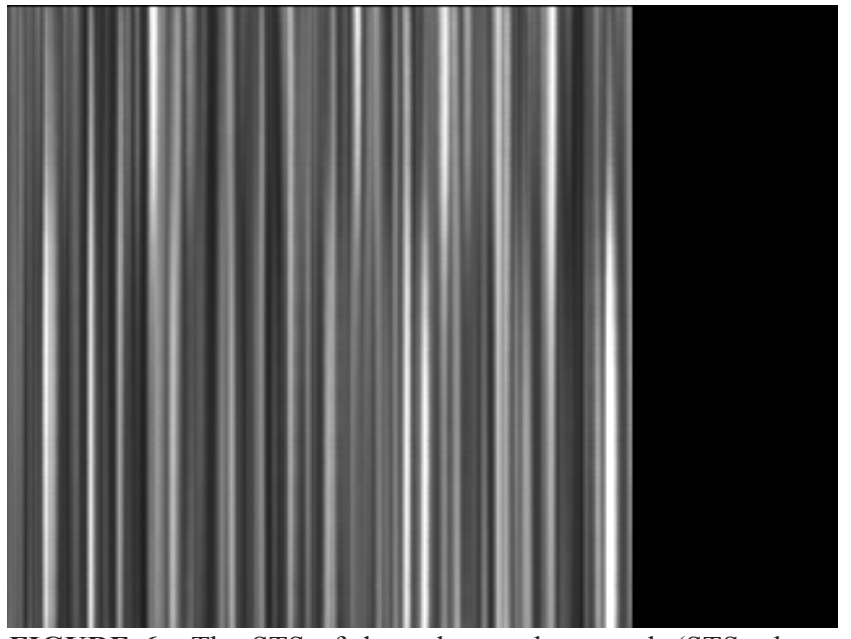

FIGURE 6 - The STS of the polypropylene mesh (STS - low activity)

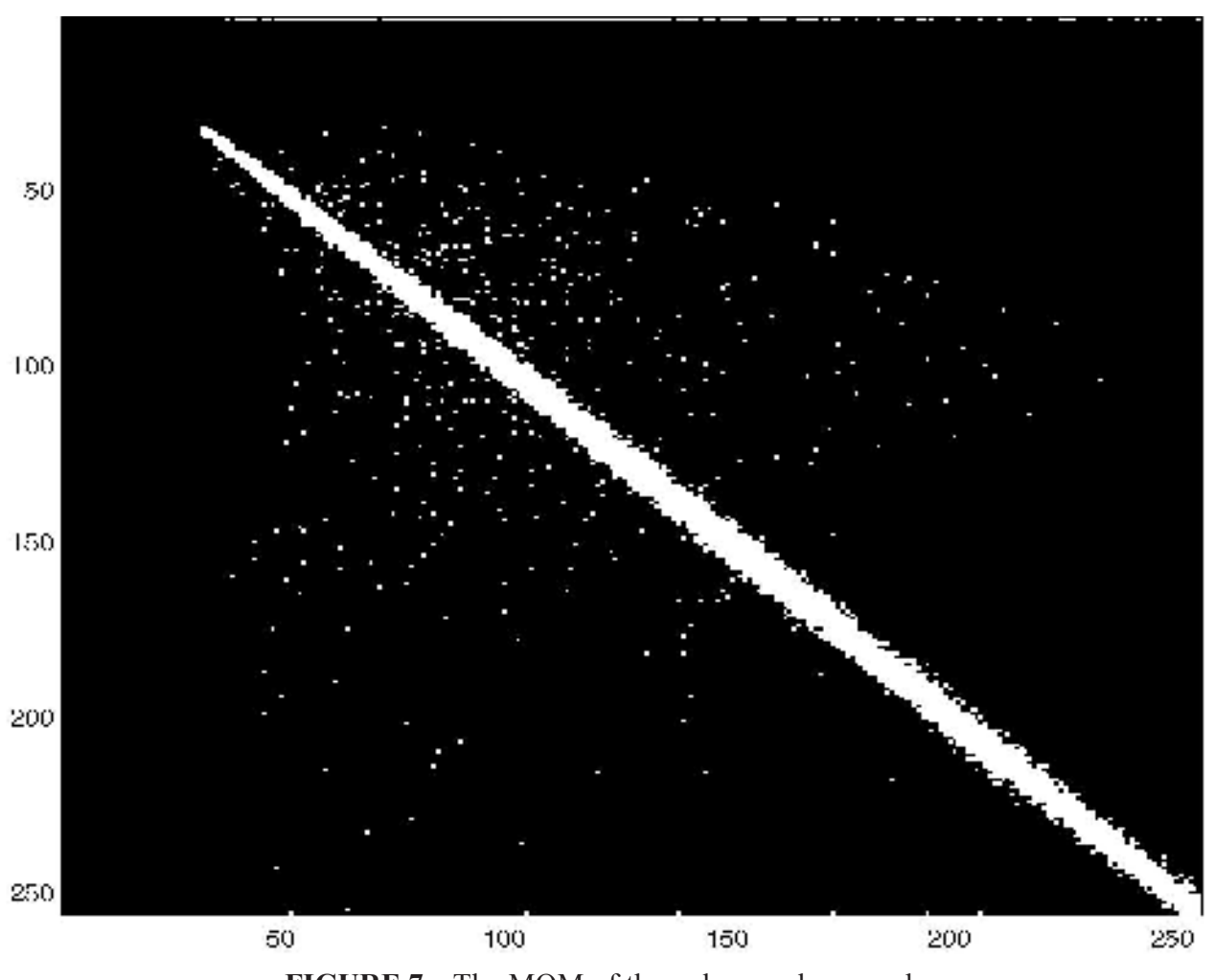

FIGURE 7 - The MOM of the polypropylene mesh

The Table 1 shows the results of the average calculations and standard deviation for each group of animals. The Table 2 shows the results of comparison of the averages for the $T$ test of
Student, and the groups were compared two to two. The statistical differences among the Groups were not significant ( $p>0.05)$. 
TABLE 1 - Median and standard deviation of each group

\begin{tabular}{c|c|c} 
Grupo & Median & Standard Deviation \\
\hline $\mathbf{1}$ & 1010,4975 & 171,7669 \\
$\mathbf{2}$ & 884,9428 & 285,1544 \\
$\mathbf{3}$ & 979,0956 & 337,4579 \\
$\mathbf{4}$ & 1072,9988 & 326,0027
\end{tabular}

TABLE 2 - Student Test $(\mathrm{T})$ comparing the medians $(\mathrm{p}>0.05)$

\begin{tabular}{|c|c|c|}
\hline $\begin{array}{c}\text { Groups } \\
\text { compared }\end{array}$ & $T$ & $p$ \\
\hline Group 1xGroup2 & 1,1800 & $0,20<p<0,30$ \\
\hline Group 1x Group 3 & 0,3315 & $0,70<p<0,80$ \\
\hline Group 1x Group 4 & 0,5300 & $0,60<p<0,70$ \\
\hline Group 2x Group 3 & 0,8008 & $0,40<p<0,50$ \\
\hline Group 2x Group 4 & 1,3730 & $0,10<p<0,20$ \\
\hline Group 3x Group 4 & 1,4720 & $0,10<p<0,20$ \\
\hline
\end{tabular}

\section{Discussion}

In spite of all the cares and procedures for hernias prevention after laparotomies, in electives or emergencies surgeries, still persist considerable percentages of incisional hernias that need surgical approach ${ }^{10,26}$. Conceptually, an incisional is an iatrogenic hernia because the patient did not present it before treating surgically an abdominal disease ${ }^{10}$, The prevention included careful preoperative prepare, good function of the respiratory, urinary and intestinal tracts in the early postoperative period, that avoids premature efforts of the abdominal wall ${ }^{9,27}$; Besides, the rigorous surgical technique, in the opening and in the closing of the wall, good irrigation and absence of tensions in the suture line and a good follow-up after the surgery, learning the patients about the important cares that must be observed, avoiding efforts ${ }^{10,28}$.

Now, although they have been established criteria for the implantation of meshs in the incisional hernias in adults, they are used broadly in the smallest muscle-aponeurotic defects and, especially, in the great eventrations ${ }^{9,10,22,29}$. Studies of the abdominal wall and its interaction with prosthetic materials, to define the gold standard in the repair of the incisional hernias have been necessary. Several experimental models were used for anatomical, histological, physiologic, biochemistries and mechanics evaluations with favorable results ${ }^{13,14,15,16,17,18}$.

This research created an experimental model for the study of the tissue activity and cicatrization of abdominal wall defects, using an optical method of analysis, the biospeckle. Were not found in the literature any references to similar studies, which is the beginning of a new thematic area of researches.

The biospeckle is a method that uses an optical phenomenon of the light Laser, already known in other areas, however only recently has been used in the analysis of biological phenomena and in medicine $e^{30,31,32,33}$. From its discovery, efforts have been determined in the exploration of the biospeckle as tool no destructive to evaluate the biological activity ${ }^{23,34,35}$. For being no destructive, it allows other studies to be made, concomitant in the same animal, which, of the experimental point of view, it is of great interest ${ }^{33}$. The cicatrization was an important factor that motivated the choice for this study. 
The Wistar rats was chosen by being of easy handling, by the authors' surgical ability in the UNICAMP Laboratories ${ }^{36}$ where they has been created and maintained in agreement with the ethics norms in animal experimentation. We employed the smallest possible number of animals, respecting the ethical demands.

Although to exist many available prosthetic materials, the polypropylene mesh was chosen due to the better results presented, in experimental ${ }^{13,14,167,17,18}$ studies and in surgical practice ${ }^{2,3,6,9,10,12,20,21}$. Researchs show that two places exist for the fixation of the mesh in a medium laparotomy: between the posterior layer of the abdominal muscles and in the posterior aponeurosis above to the parietal peritoneum ${ }^{10}$. In this model, the second option as a preperitonial repair it was adopted, considering the anatomical characteristics of the animal, that it presents the posterior aponeurosis layer of extremely thin, making unfeasible its dissection of the muscular plan. Technically, there was little difficulty in unsticking the parietal peritonium, since he was opened simultaneously to the musculature. Following, after its identification, in the border of the incision, the dissection began using scalpel, allowing a small margin that was repaired in two points. This repair allowed the traction of layer and its releasing using blunt dissection, maintaining the vasculatization of the muscular plan, avoiding hemorrhage or tissue necrosis. It is important to emphasize that without the previous peritoneum opening, this procedure would not be possible.

The mesh, after its positioning in the preperitonial space, it was sutured to the muscular wall, in their four angles, using separated 5-0 polypropylene stitches, in agreement with the literature as for the use of a same material for the mesh ${ }^{10}$. The suture with polypropylene stitches permitted to maintain the mesh immobile until its adherence to the wall, inducing its incorporation to the neighboring tissues. The anterior aponeurosis also received a continuous suture, with polypropylene stitches, so that only this material was in contact with the mesh.

It was chosen the 20th postoperative day as the time for the optical studies by being the moment in that the cicatrization, in rats, is in the fibrosis phase. The great complexity of the biological organisms does with that the acquisition of the images presents a level of larger complexity than in the specimens no biological. Some difficulties in the acquisition of the data were due to the breathing movements of the rats that worked as optical noise. This fact and the great tissue activity of the animal determined that the time of acquisition of the images was the smallest allowed by the equipment, to minimize interferences. Essays using a cutaneous contact sensor would not be subject to the interference of the breathing movement, but this device was not available yet. Initially, there was the supposition that there would be significant differences among the groups, however the results did not confirm. Maybe a larger postoperative period of studies, or a larger number of animals accentuated the small verified differences

Finally, the homogeneity of the results and the rigorous standardization of the research, it allowed the conclusion that this model is viable. This is an initial research that open ways for a great number of experiments to be developed in evaluating tissue activity. The biospeckle method presents a great potential for experiments combined with biochemical analyses and histological dynamics, in pathological situations of sepsis or shock, as well as studies of the early or later cicatrization, their normal variations and defects, among others.

\section{Conclusions}

The analysis of the obtained data permitted to conclude that the animal model employed is viable and reproducible. There was not statistical differences in the four study groups of the tissue activity of the abdominal wall of the animals, with and without the surgical implantation of polypropylene mesh, when analyzed by the biospeckle.

\section{References}

1. Rosenberg D, Vianna FC. O uso de material plástico na cura das hérnias recidivadas e incisionais. Rev Paul Med. 1957;51 (2):37-47.

2. Uscher FC, Ochsner J, Tutle Jr LLD. Use of Marlex ${ }^{\circledR}$ mesh in the repair of incisional hernia. Am Surg. 1958;24(12):969-74.

3. Uscher FC, Gannon JP. Marlex ${ }^{\circledR}$ mesh, a new plastic mesh for replacing tissue defects. Arch Surg. 1959;78(1):131-45.

4. Rubio PA. New technique for repairing large ventral incisional hernias with Marlex ${ }^{\circledR}$ mesh. Surg Gynecol Obstet. 1986;162(3):275-6.

5. Chacon JP, Kobata CMY, Prado Kobata MHP. Hérnias incisionais abdominais: correção com tela de Marlex ${ }^{\circledR}$. Rev Col Bras Cir. 1989;16(3):99-103.

6. Lichtenstein IL, Shulman AG, Amid PK. The tension-free hernioplasty. Am J Surg. 1989;157(2):188-93.

7. Stoppa RE. The treatment of complicated groin and incisional hernias. World J Surg. 1989;13(5):545-54.

8. Pitrez FAB, Lemchen HF, Furtado JP. Correção cirúrgica dos grandes defeitos da parede abdominal com uso de tela de Marlex ${ }^{\circledR}$. Rev Col Bras Cir. 1990;17(3):41-5.

9. Cameron AEP, Gray RC, Talbot RW, Wyatt AP. Abdominal wound closure: a trial of Prolene ${ }^{\circledR}$ and Dexon ${ }^{\circledR}$. Br J Surg. 1980;67(7):487-8.

10. Gupta H, Srivastava A, Menon GR, Agrawal CS, Chumber S, Kumar S. Comparison of interrupted versus continuous closure in abdominal wound repair: a meta-analysis of 23 trials. Asian J Surg. 2008;31(3):104-14.

11. Abdalla P. Herniorrafias abdominais - Análise da incidência em 2000 casos. Rev Col Bras Cir. 1981;8(2):67-9.

12. Tinoco RA, Tinoco LA, Rigueira SE, Cacichiri QN, Henney GT. Hérnia incisional: correção com tela de polipropileno. Rev Bras Cir. 1981;71(2):97-100.

13. Arnaud JP, Eloy R, Adloff M, Grenier JF. Critical evaluation of prosthetic materials in repair of abdominal wall hernias: new criteria of tolerance and resistance. Am J Surg. 1977;133(3):338-45.

14. Bellón Carneiro JM, Contreras Alarcón LA, Palomares Rabadán D, Buján Varela J, carrera san-martín A. Influencia del tamaño de poro en la resistencia biomecánica postimplante de diferentes tipos de prótesis de polipropileno. Cir Esp. 1998;64:190-6.

15. Bellón Carneiro JM, Contreras Alarcón LA, Buján Varela J, Palomares Rabadán D, Carrera San-Martín A. Tissue response to polypropylene meshes used in the repair of abdominal wall defects. Biomaterials. 1998;19(7-9):669-75.

16. PalmierI B, GozzI G, Palmieri G, Marzona L. Studio sperimentale sull'applicazione di reti sintetiche in corso di grandi sventramenti addominali. Minerva Chir. 1999;54(7-8):537-43.

17. Francioni G, Ansaldo V, Magistrelli N, Pari AM, Rinaldi P, Sani C, Rafaeli W, Pari G. The use of prosthesis in abdominal wall defect, 15 year experience: evaluation of tissue reactions and complications. Chir Ital. 1999;51(1):21-30.

18. Greca FH, De Paula JB, Biondo-Simões ML, Da Costa FD, Da Silva AP, Time S, Mansur A. The influence of differing pore sizes on the biocompatibility of two polypropylene meshes in the repair of abdominal defects. Experimental study in dogs. Hernia. 2001;5(2):59-64.

19. Amid PK, Shulman AG, Lichtenstein IL, Hakakha M. Biomaterials for abdominal wall hernia surgery and principles of their applications. Langenbecks Arch Surg. 1994;379(3):168-71. 
20. Uscher FC. New technique for repairing incisional hernias with Marlex ${ }^{\mathbb{B}}$ mesh. Am J Surg. 1979;138(5):740-1.

21. Amid PK, Shulman AG, Lichtenstein IL. A simple stapling technique for prosthetic repair of massive incisional hernias. Am Surg. 1994;60(12):934-37.

22. Uscher FC. The repair of incisional and inguinal hernias. Surg Gynecol Obstet. 1970;131(3):525-30.

23. Nascimento AL, Costa Jr AT, Rabelo GF, Braga Jr RA. Desenvolvimento de um modelo para o biospeckle na análise de sementes de feijão (Phaseolus vulgaris L.). Ciênc Agrotec. 2007;31(2):456-61.

24. Cheng H, Luo Q, Liu Q, Lu Q, Gong H, Zeng S. Laser speckle imaging of blood flow in microcirculation. Phys Med Biol. 2004;49(7):1347-57.

25. Rabelo GF. Avaliação da aplicação do Biospeckle dinâmico no monitoramento da qualidade da laranja [Tese]. Faculdade de Engenharia Agrícola, Universidade Estadual de Campinas; 2000.

26. Rutkow IM. The recurrence rate in hernia surgery. Arch Surg. 1995;130(6):575-6.

27. Labbate DV, Andreollo NA, Barcelos Neto HS, Peres MAO, Oliveira C, Barreto G, Moraes GR, Seabara JCT, Leonardi LS. A importância dos exames subsidiários na avaliação pré-operatória em hospital comunitário: análise de 1500 pacientes. Rev Col Bras Cir. 1995;22(3):131-6.
28. Rives J, Lardennois B, Pire JC, Hibon J. Les grandes éventrations. Importance du volet abdominal et des troubles respiratoires qui lui sont secondaires. Chirurgie. 1973;99(8):547-63.

29. Matapurkar BG, Gupta AK, Agarwal AK. A new technique of "Marlex ${ }^{\circledR}$-peritoneal sandwich" in the repair of large incisional hernias. World J Surg. 1991;15(6):768-70.

30. Dainty JC. Laser speckle and related phenomena. Appl Opt. 1984;23(16):2661.

31. Asakura T, Takai N. Dynamic laser speckles and their applications to velocity measurements of the diffuse object. J Appl Phys. 1981;25:179-94. 32. Ruth B. Non-contact blood flow determination using a laser speckle method. Optic Laser Technol. 1998;20:309-16.

33. Oulamara A, Tribillon G, Duvernoy J. Biological activity measurement on botanical specimen surface using temporal decorrelation effect of laser speckle. J Mod Optics. 1989;36(2):165-79.

34. Rabal HJ, Arizaga R, Trivi MR, Romero GG, Alanis E. Transient phenomena analysis using dynamic speckle patterns. Opt Eng. 1995;35(1):57-63.

35. Briers JD. Speckle fluctuations and biomedical optics: implications and applications. Optic Engineering. 1993;32:277-83.

36. Nieri TM. Estudo sobre o comportamento mecânico do cólon integro e com anastomose - Trabalho experimental em ratos [Dissertação]. Faculdade de Ciências Médicas, Universidade Estadual de Campinas; 999.

\section{Correspondence:}

Tâmara Maria Nieri

Rua Benjamin Arruda, 185

12.914-560 Bragança Paulista - SP Brazil

tamaraspbr@yahoo.com.br

Conflict of interest: none

Financial source: none

Received: April 14, 2009

Review: June 10, 2009

Accepted: July 15, 2009

\section{How to cite this article}

Nieri TM, Peres MAO, Silva ER, Dal Fabbro IM, Muramatsu M, Andreollo NA. The optical analysis of the abdominal wall using the biospeckle after implants of polypropylene mesh in rats. Acta Cir Bras. [serial on the Internet] 2009 Nov-Dec;24(6). Available from URL: http://www.scielo.br/acb 